\title{
Katalitik hidrogenasi lateks karet alam dengan senyawa diimida pada skala semi pilot
}

\section{Catalytic diimide hydrogenation of natural rubber latex at semi pilot scale}

\author{
Santi Puspitasari*, Adi Cifriadi \\ Pusat Penelitian Karet, Jalan Salak Nomor 1 Bogor 16151 Jawa Barat, Indonesia \\ *Penulis korespondensi. Telp: +62 2518319817 , Fax : +62 2518324047 \\ E-mail: puspitasari.santi@puslitkaret.co.id
}

Diterima: 29 Agustus 2017 Direvisi: 8 November 2017 Disetujui: 11 November 2017

\begin{abstract}
Improvement on thermal oxidative resistance of natural rubber can strenghten its application especially on the manufacture of outdoor rubber goods. Thermal oxidative resistant natural rubber can be synthesized by diimide hydrogenation, generated insitu from oxidation of hyrazine hydrate with hydrogen peroxide. The research studied diimide hydrogenation of natural rubber latex at semi pilot scale of capacity $2.5 \mathrm{~kg}$ latex/batch. The reaction used boric acid as catalyst, and combination of anionic/nonionic surfactants to maintain the latex stability during reaction. Variables of reaction include temperature $\left(40\right.$ and $\left.50^{\circ} \mathrm{C}\right)$ and proportion of hydrazine hydrate/hydrogen peroxide. Based on the qualitative and quantitative analysis, the optimum condition of diimide hydrogenation was achieved at $50^{\circ} \mathrm{C}$ with proportion of hydrazine hydrate/hydrogen peroxide as 42.5/35 phr. The hydrogenated natural rubber has better thermal oxidative resistance compare to unmodified natural rubber since it has tough and hard textures, highest plasticity retention index as $38.5 \%$ and degree of hydrogenation as $60.48 \%$, and lowest gel content as $56.98 \%$.
\end{abstract}

Keywords: Diimide, natural rubber, thermal oxidative resistance, hydrogenation.

\begin{abstract}
ABSTRAK
Peningkatan ketahanan oksidasi termal karet alam dapat memperluas aplikasinya terutama untuk pembuatan produk karet yang diaplikasikan di luar ruangan. Karet alam tahan oksidasi termal dapat dibuat secara hidrogenasi menggunakan senyawa diimida yang dihasilkan secara insitu dari oksidasi hidrasina hidrat oleh hidrogen peroksida. Pada riset ini dipelajari kondisi optimum reaksi hidrogenasi lateks karet alam pada skala semi pilot berkapasitas 2,5 $\mathrm{kg}$ lateks pekat/batch berkatalis asam borat. Sistem kestabilan koloid lateks selama reaksi dipertahankan dengan penambahan kombinasi surfaktan anionik/nonionik. Variabel yang ditetapkan dalam reaksi meliputi suhu (40 dan $50^{\circ} \mathrm{C}$ ) dan rasio konsentrasi hidrasina hidrat (40 dan 42,5 phr) terhadap hidrogen peroksida (30 dan $35 \mathrm{phr}$ ). Berdasarkan hasil analisis kualitatif dan kuantitatif terhadap karet terhidrogenasi diketahui bahwa kondisi optimal reaksi hidrogenasi lateks karet alam dicapai pada suhu $50^{\circ} \mathrm{C}$ dengan rasio konsentrasi hidrasina hidrat/hidrogen peroksida sebesar 42,5/35 phr. Pada kondisi reaksi tersebut, karet terhidrogenasi memiliki sifat ketahanan oksidasi termal yang lebih baik dibandingkan karet alam murni yang ditunjukkan dengan wujud bertekstur kokoh, keras, dan tidak lengket, indeks ketahanan plastisitas tertinggi sebesar 38,5\% dan derajat hidrogenasi sebesar 60,48\%. Karet hidrogenasi tersebut juga memiliki kadar gel yang rendah sebesar 56,98\%.
\end{abstract}

Kata kunci: Diimida, karet alam, ketahanan oksidasi termal, hidrogenasi.

\section{PENDAHULUAN}

Karet alam Hevea brasiliensis Muell Arg merupakan biopolimer yang tersusun atas monomer isoprena yang saling berikatan membentuk rantai panjang cis 1,4-poliisoprena. Rantai panjang poliisoprena mengakibatkan karet alam memiliki sifat mekanik yang unggul namun keberadaan ikatan rangkap $\mathrm{C}=\mathrm{C}$ justru menyebabkan karet alam tidak tahan terhadap proses oksidasi termal sehingga membatasi apikasinya terutama untuk keperluan luar ruangan (Arayapranee \& Rempel, 2009; Kongparakul et al., 2011; Piya-areetham et 
al., 2013a). Akibatnya dalam memproduksi produk karet untuk aplikasi luar ruangan yang terpapar langsung oleh sinar matahari, ozon, dan oksigen harus dikombinasikan dengan karet sintetik yang tahan terhadap oksidasi termal seperti karet EPDM, karet CR, dan karet butil. Alternatif solusi lain adalah dengan memodifikasi kimiawi sifat karet alam secara hidrogenasi. Reaksi hidrogenasi terhadap molekul karet alam mengkonversi ikatan tak jenuh $\mathrm{C}=\mathrm{C}$ menjadi ikatan jenuh $\mathrm{C}-\mathrm{C}$ yang bersifat tidak reaktif terhadap proses oksidasi termal tanpa memutus rantai molekul karet alam tersebut. Sehingga melalui metode ini diharapkan karet alam mampu mempertahankan sifat mekaniknya yang unggul dan menjadi lebih tahan terhadap proses oksidasi termal (Piya-areetham, et al., 2013b). Karet alam terhidrogensi memiliki struktur rantai molekul menyerupai karet EPDM (Inoue \& Nishio, 2007).

Proses hidrogenasi karet alam dapat dilakukan pada fasa lateks secara hidrogenasi menggunakan senyawa diimida yang terbentuk dari oksidasi hidrasin hidrat oleh hidrogen peroksida. Reaksi hidrogenasi lateks karet alam berlangsung dengan mengikuti mekanisme yang dijelaskan oleh Lin et al. (2004) sebagai berikut:

$$
\begin{gathered}
\mathrm{N}_{2} \mathrm{H}_{4}+\mathrm{H}_{2} \mathrm{O}_{2} \rightarrow \mathrm{N}_{2} \mathrm{H}_{2}+2 \mathrm{H}_{2} \mathrm{O} \\
\mathrm{N}_{2} \mathrm{H}_{2}+-\mathrm{HC}=\mathrm{CH}-\rightarrow \mathrm{N}_{2}+-\mathrm{H}_{2} \mathrm{C}-\mathrm{CH}_{2}-
\end{gathered}
$$

Metode ini memiliki keunggulan dibandingkan hidrogenasi konvensional yang menggunakan gas $\mathrm{H}_{2}$ karena dapat dijalankan hanya dengan penambahan katalis homogen dan memiliki selektivitas yang tinggi serta dijalankan pada tekanan atmosferis (Mahittikul et al., 2009; Wang \& Astruc, 2015). Keberhasilan reaksi hidrogenasi sangat bergantung pada rasio konsentrasi hidrasina hidrat/hidrogen peroksida, jenis dan dosis katalis dan bahan penstabil reaksi, serta kondisi reaksi (suhu dan waktu). Mahittikul et al. (2007) telah mengujicobakan berbagai katalis dalam reaksi hidrogenasi lateks karet alam dengan penambahan surfaktan SDS sebagai bahan penstabil. Berdasarkan hasil riset diketahui bahwa penggunaan SDS menurunkan derajat hidrogenasi lateks karet alam pekat yang dikatalis oleh tembaga sulfat. Sedangkan katalis teroptimum untuk reaksi hidrogenasi karet alam dipilih dari jenis tembaga asetat. Selanjutnya reaksi hidrogenasi non katalitik pada berbagai jenis lateks telah dipelajari oleh Veni dan Ma'zam (2010) yang menemukan bahwa lateks karet alam segar dapat mencapai derajat hidrogenasi tertinggi dibanding jenis lateks pekat dan DPNR.

Cifriadi et al. (2017a) mempelajari pengaruh rasio konsentrasi hidrasina hidrat/hidrogen peroksida pada reaksi hidrogenasi lateks pekat berpengawet $\mathrm{NaOH}$ pada suhu $70^{\circ} \mathrm{C}$. Dari hasil riset diketahui bahwa bertambahnya dosis hidrogen peroksida menyebabkan terbentuknya reaksi samping depolimerisasi pada molekul karet alam akibat terbentuknya radikal bebas hidroksil dari sisa hidrogen peroksida yang tidak bereaksi. Temuan ini sejalan dengan hasil riset sebelumnya yang telah dilakukan oleh Lin et al. (2004) dan Mahittikul et al. (2006). Sistem penstabil lateks dengan surfaktan anionik SDS pada reaksi hidrogenasi lateks DPNR berkatalis (asam borat, tembaga sulfat, dan tembaga asetat) turut dipelajari oleh Cifriadi et al. (2017b). Hasil riset menunjukkan bahwa katalis tembaga sulfat dan tembaga asetat yang bersifat prooksidan memicu terjadinya pemutusan ikatan rangkap $\mathrm{C}=\mathrm{C}$ pada rantai molekul karet alam sehingga karet terhidrogenasi berwujud semi-solid menyerupai pasta yang lengket. Penggunaan surfaktan pada dosis 1 phr menyebabkan sistem koloid lateks menjadi terlalu stabil akibatnya menjadi sulit digumpalkan di akhir reaksi dan hanya diperoleh rendemen karet yang rendah.

Pada naskah ini diuraikan mengenai prosedur reaksi hidrogenasi lateks karet alam pekat menggunakan senyawa diimida pada skala semi pilot berkapasitas $2,5 \mathrm{~kg}$ lateks pekat/batch berkatalis asam borat. Reaksi diatur pada berbagai rasio konsentrasi hidrasina hidrat/hidrogen peroksida dan suhu. Sistem kestabilan lateks dipertahankan dengan penambahan kombinasi surfaktan anionik/ nonionik agar sistem koloid lateks tetap stabil sepanjang reaksi hidrogenasi namun mudah digumpalkan di akhir reaksi. Kondisi reaksi hidrogenasi teroptimum ditentukan berdasarkan nilai derajat hidrogenasi dan indeks ketahanan plastisitas karet terhidrogenasi. Parameter kadar gel turut dianalisis sebagai indikator terjadinya reaksi samping pembentukan ikatan silang (cross link).

\section{BAHAN DAN METODE Bahan Penelitian}

Bahan utama yang digunakan dalam penelitan ini meliputi lateks karet alam pekat kadar amonia tinggi (high ammoniated natural rubber latex, HANR) dengan kadar karet kering (KKK) sebesar 
$58 \%$ yang diperoleh melalui Koperasi Karyawan INIRO, Bogor, hidrasina hidrat $\left(\mathrm{N}_{2} \mathrm{H}_{4}\right.$ teknis kemurnian 35\%) dari PT. Insoclay Acidatama Indonesia, Cikarang, hidrogen peroksida $\left(\mathrm{H}_{2} \mathrm{O}_{2}\right.$ teknis kemurnian 30\%) dari CV. Setia Guna, Bogor. Selanjutnya surfaktan anionik sodium lauril sulfat (SLS) dan non ionik polioksietilen fenil eter yang berfungsi sebagai penstabil lateks didapatkan dari PT. KAO Indonesia. Katalis asam borat (kemurnian 99\%) didapat dari Merck Jerman. Natrium tiosulfat sebagai penetral sisa hidrogen peroksida dan $\mathrm{CaCl}_{2}$ untuk penggumpal juga diperoleh dari CV. Setia Guna Bogor. Bahan kimia untuk karakterisasi bilangan iod meliputi pereaksi Wijs, kloroform $\left(\mathrm{CHCl}_{3}\right)$, natrium tiosulfat $\left(\mathrm{Na}_{2} \mathrm{~S}_{2} \mathrm{O}_{5}\right)$, kalium iodida (KI), indikator kanji, asam klorida $(\mathrm{HCl})$, dan kalium dikromat $\left(\mathrm{K}_{2} \mathrm{Cr}_{2} \mathrm{O}_{7}\right)$ seluruhnya diperoleh dari Merck Jerman pada spesifikasi pro analys.

\section{Peralatan Penelitian}

Reaksi hidrogenasi lateks karet alam dengan senyawa diimida pada skala semi pilot berkapasitas 2,5 kg lateks pekat/batch dijalankan dalam reaktor tangki berpengaduk yang dilengkapi dengan pengaduk mekanis dengan inventer, jacket heater dengan media pemanas air dan seperangkat alat pengendali suhu. Laboratory glassware yang digunakan untuk analisis meliputi buret selbach, erlenmeyer, beaker glass, gelas ukur, corong pemisah, corong kaca, dan cawan petri. Instrumen untuk karakterisasi sifat kimia mencangkup fourier transform infra red (FTIR) spektometer tipe Nicolet i5 dari Thermoscientific untuk uji gugus fungsi molekul dan Wallace Plastimeter untuk pengujian indeks ketahanan plastisitas karet.

\section{Metode Penelitian}

Pembuatan karet alam terhidrogenasi dari lateks karet alam pekat kadar amonia tinggi dengan senyawa diimida pada skala semi pilot mengikuti tahapan sebagai berikut: $2,5 \mathrm{~kg}$ lateks pekat dituangkan ke dalam reaktor, selanjutnya ditambah dengan $0,5 \mathrm{phr}$ surfaktan SLS 5\%, dan $0,5 \mathrm{phr}$ surfaktan polioksietilen fenil eter $5 \%$, serta $0,05 \mathrm{phr}$ katalis asam borat $10 \%$. Campuran dalam reaktor terus diaduk pada kecepatan $100 \mathrm{rpm}$. Suhu diatur pada suhu reaksi sebesar $40{ }^{\circ} \mathrm{C}$ dan $50{ }^{\circ} \mathrm{C}$. Ketika tercapai suhu reaksi, ke dalam campuran ditambahkan dengan hidrasin hidrat 35\% (40 dan 42,5 phr) dan hidrogen peroksida 30\% (30 dan 35 phr). Reaksi berlangsung selama 6 jam. Pada 30 menit sebelum reaksi berakhir, ke dalam lateks hidrogenasi ditambahkan $0,5 \mathrm{phr}$ larutan natrium tiosulfat $10 \%$ untuk menetralkan sisa hidrogen peroksida yang tidak bereaksi. Lateks hidrogenasi yang diperoleh di akhir reaksi digumpalkan menggunakan larutan $\mathrm{CaCl}_{2} 5 \%$. Gumpalan karet terhidrogenasi kemudian dicuci dalam air mengalir dan direndam dalam air bersih selama 20 jam untuk menghilangkan sisa reaktan. Gumpalan karet terhidrogeasi digiling dalam mesin kreper hingga menjadi lembaran karet terhirogenasi. Lembaran karet terhidrogenasi basah dikering-anginkan selama 24 jam sebelum dikeringkan dalam oven pada suhu $100^{\circ} \mathrm{C}$ selama 3 jam. Lembaran karet terhidrogenasi kering kemudian dikarakterisasi.

Karakterisasi karet hidrogenasi dilakukan secara kualitatif maupun kuantitatif. Analisis kualitatif meliputi uji visual dan uji gugus fungsi menggunakan FTIR, sedangkan analisis kuantitatif mencakup parameter derajat hidrogenasi, indeks ketahanan plastisitas, dan kadar gel.

\section{Analisis FTIR}

Spektra FTIR karet hidrogenasi dianalisis pada bilangan gelombang antara $4000-500 \mathrm{~cm}^{-1}$. Untuk setiap sampel karet, pemindaian dengan FTIR dilakukan sebanyak 2 kali. Gugus fungsi dalam karet alam murni digunakan sebagai pembanding.

\section{Derajat hidrogenasi}

Derajat hidrogenasi ditetapkan sebagai ukuran konversi reaksi hidrogenasi lateks karet alam. Derajat hidrogenasi ditentukan berdasarkan nilai bilangan iod yaitu dengan membandingkan nilai bilangan iod karet terhidrogenasi dengan karet alam murni (Persamaan (1)). Pada riset ini, pengujian bilangan iod mengacu pada Metode Wijs (Cifriadi et al., 2017a). Bilangan iod umumnya digunakan untuk menggambarkan tingkat ketidakjenuhan senyawa.

Derajat hidrogenasi $=\frac{\mathrm{C}_{\mathrm{O}}-\mathrm{C}}{\mathrm{C}_{\mathrm{O}}} \times 100 \%$

$\mathrm{C}_{\mathrm{O}}$ adalah bilangan iod karet alam murni dan $\mathrm{C}$ adalah bilangan iod karet alam terhidrogenasi.

\section{Indeks Ketahanan Plastisitas (PRI)}

Pengukuran indeks ketahanan plastisitas diperlukan untuk mengetahui ketahanan karet mentah terhadap proses oksidasi termal. Indeks ketahanan plastisitas merupakan persen rasio plastisitas karet 
setelah pengusangan terhadap sebelum pengusangan (Persamaan (2)). Kondisi pengusangan pada pengujian ini ditetapkan pada $140{ }^{\circ} \mathrm{C}$ selama 30 menit. Metode uji indeks ketahanan plastitas mengacu pada ASTM D 3194-04.

$\mathrm{PRI}=\frac{\mathrm{P}_{\mathrm{a}}}{\mathrm{P}_{\mathrm{O}}} \times 100 \%$

$\mathrm{P}_{\mathrm{a}}$ adalah plastisitas setelah pengusangan dan $\mathrm{P}_{\mathrm{O}}$ adalah plastisitas sebelum pengusangan.

\section{Kadar gel}

Prosedur dalam pengujian kadar gel memodifikasi metode yang dikembangkan oleh Veni dan Ma'zam (2010) sebagai berikut: sampel karet terhidrogenasi ditimbang seberat 0,125 gram. Sampel tersebut dilarutkan dalam $25 \mathrm{ml}$ kloroform selama 20 jam. Hasil pelarutan kemudian disaring menggunakan kertas saring. Residu hasil penyaringan yang mengandung makro gel dikeringkan dalam oven pada suhu $100{ }^{\circ} \mathrm{C}$ hingga diperoleh bobot konstan. Penentuan kadar gel mengikuti Persamaan (3) berikut:

$$
\text { Kadar gel }=\frac{\text { Bobot gel }}{\text { Bobot sampel karet awal }} \times 100 \%
$$

\section{HASIL DAN PEMBAHASAN}

Analisis visualisasi fisik karet terhidrogenasi dimaksudkan sebagai indikator awal keberhasilan terbentuknya karet terhidrogenasi. Visualisasi fisik karet hidrogenasi ditampilkan pada Gambar 1. Dari Gambar 1 terlihat adanya perbedaan warna pada lembaran karet terhidrogenasi. Lembaran karet terhidrogenasi basah berwarna putih, kemudian berubah menjadi putih kekuningan pada lembaran karet terhidrogenasi setengah kering kemudian berubah menjadi berwarna coklat pada lembaran karet terhidrogenasi kering, sedangkan pada lembaran karet alam murni kering berwarna kuning. Seluruh karet terhidrogenasi yang diperoleh berwujud padat dan memiliki tekstur yang kuat, kokoh, dan keras. Visualisasi fisik lembaran karet terhidrogenasi kering membuktikan bahwa proses penetralan sisa hidrogen peroksida dengan natrium tiosulfat berlangsung efektif, sehingga meminimalisasi terjadinya reaksi samping depolimerisasi. Terjadinya reaksi depolimerisasi pada karet alam dicirikan dengan fisik karet yang berwujud semi-solid menyerupai pasta, bertekstur lengket dan berwarna cokelat gelap.

Terbentuknya karet hidrogenasi dikonfirmasi dengan hasil analisis spektroskopi FTIR. Spektra FTIR karet terhidrogenasi dibandingkan dengan karet alam murni disajikan pada Gambar 2. Dari Gambar 2 dapat diketahui bahwa spektra FTIR karet alam dicirikan oleh adanya serapan tajam pada puncak bilangan gelombang $1662 \mathrm{~cm}^{-1}$ (ikatan rangkap tak jenuh $\mathrm{C}=\mathrm{C}$, vibrasi ulur) dan 834 $\mathrm{cm}^{-1}$ (ikatan $=\mathrm{C}-\mathrm{H}$, vibrasi tekuk) (Ibrahim et al., 2014). Puncak serapan lain yang terdapat pada rantai molekul karet alam antara lain $2960 \mathrm{~cm}^{-1}$ (ikatan $\mathrm{CH}_{3}$, vibrasi ulur), $1446 \mathrm{~cm}^{-1}$ (ikatan $\mathrm{CH}_{3}$, vibrasi tekuk), $2850 \mathrm{~cm}^{-1}$ (ikatan $\mathrm{CH}_{2}$, vibrasi ulur), $1375 \mathrm{~cm}^{-1}$ (ikatan $\mathrm{CH}_{2}$, vibrasi tekuk), dan $739 \mathrm{~cm}^{-1}$ (ikatan - $\left.\left(\mathrm{CH}_{2}\right)_{3}\right)$ (Mahittikul et al., 2007; Mahittikul et al., 2009; Arayapranee \& Rempel, 2013). Sementara itu pada spektra FTIR karet terhidrogenasi nampak terjadinya penurunan intensitas puncak serapan pada bilangan gelombang $1662 \mathrm{~cm}^{-1}$ dan $834 \mathrm{~cm}^{-1}$ yang diikuti dengan peningkatan intensitas pada puncak serapan $739 \mathrm{~cm}^{-1}$ serta munculnya puncak serapan baru pada bilangan gelombang $2726 \mathrm{~cm}^{-1}$ (ikatan $\mathrm{O}=\mathrm{CH}$, vibrasi ulur) (Puviarasan et al., 2004). Reaksi hidrogenasi menyebabkan tereliminasinya ikatan rangkap tak

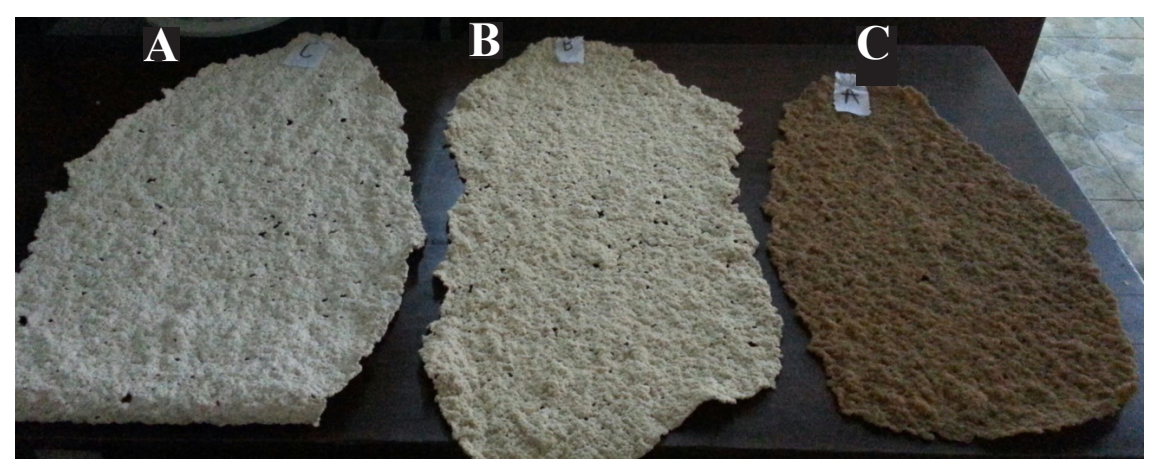

Gambar 1. Visualisasi fisik lembaran HNR pada berbagai kondisi : basah (A), setengah kering (B), dan kering $(\mathrm{C})$. 


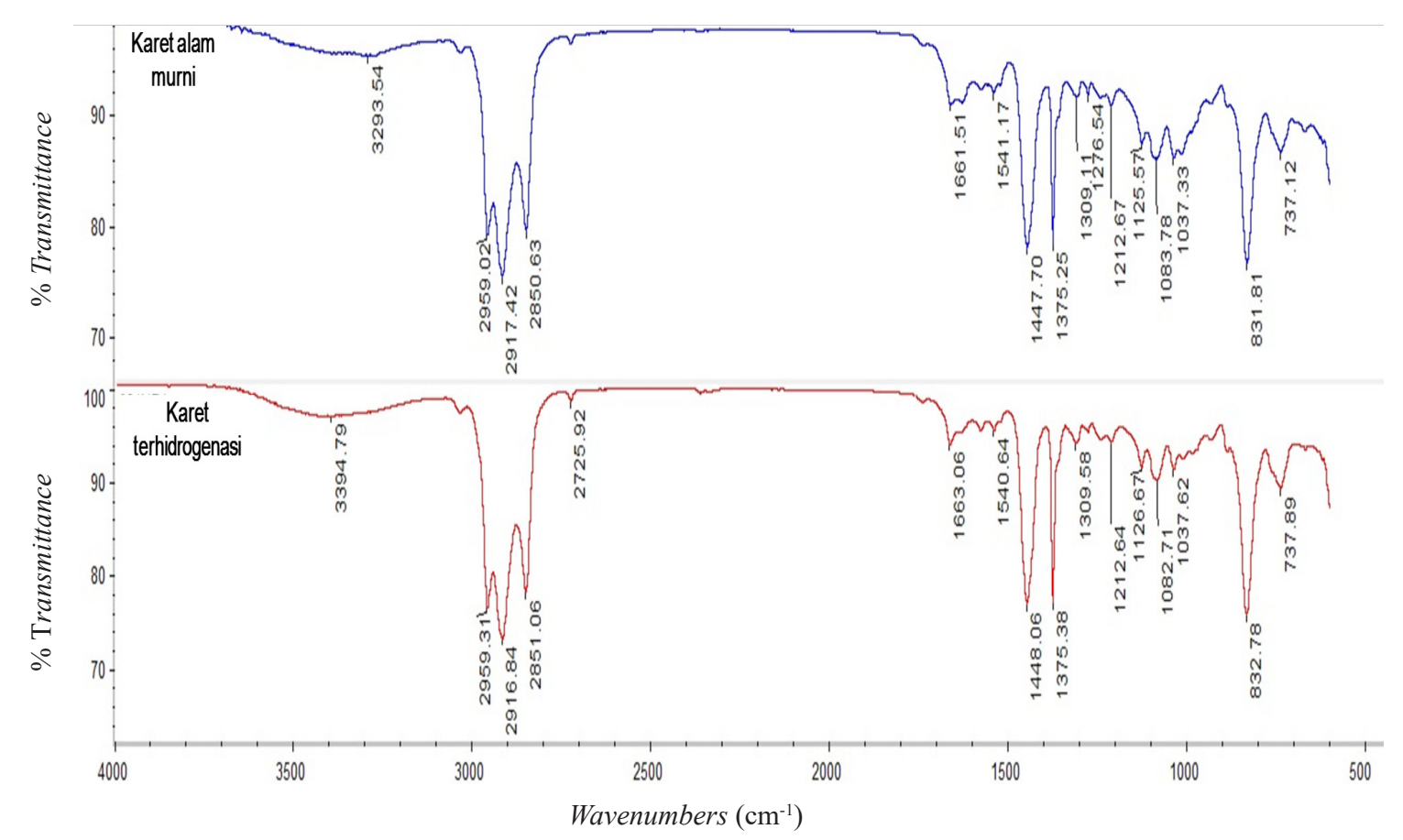

Gambar 2. Spektra FTIR karet alam murni dan karet terhidrogenasi.

jenuh $\mathrm{C}=\mathrm{C}$ menjadi ikatan tunggal jenuh $\mathrm{C}-\mathrm{C}$. Atom hidrogen dari senyawa diimida mengadisi ikatan $\mathrm{C}=\mathrm{C}$ sehingga terputus menjadi ikatan $\mathrm{C}-\mathrm{C}$, sedangkan munculnya gugus aldehida $(\mathrm{O}=\mathrm{CH})$ diperkirakan karena terjadinya reaksi samping pembentukan ikatan silang antar sebagian senyawa non karet akibat penggunaan hidrogen peroksida.

Derajat hidrogenasi yang menggambarkan konversi ikatan rangkap $\mathrm{C}=\mathrm{C}$ menjadi ikatan tunggal C-C dalam struktur rantai molekul karet terhidrogenasi disajikan pada Gambar 3. Berdasarkan Gambar 3 tampak bahwa nilai derajat hidrogenasi pada karet hasil modifikasi yang diperoleh saling berdekatan yaitu antara 59,48-61,11\%. Kondisi ini

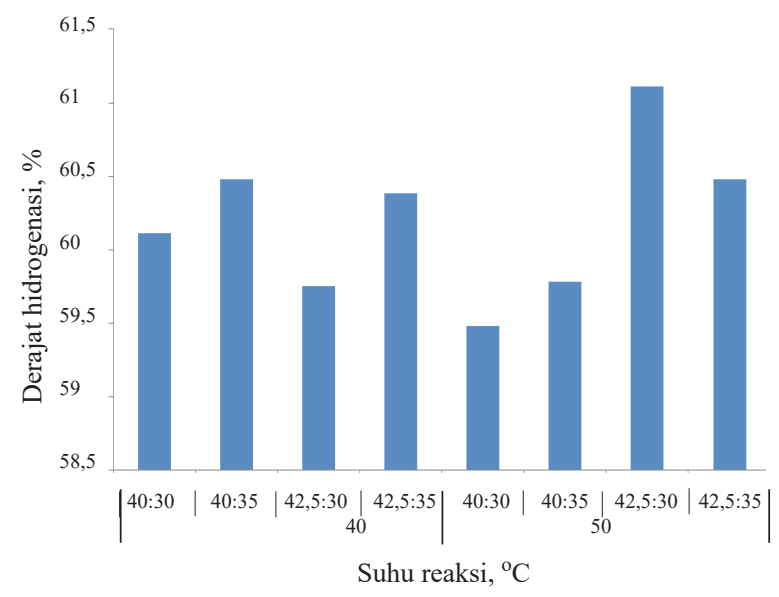

Gambar 3. Derajat hidrogenasi pada karet terhidrogenasi. berarti bahwa meskipun reaksi hidrogenasi merupakan fungsi dari suhu reaksi dan rasio konsentrasi hidrasina hidrat/hidrogen peroksida, namum pada riset ini kondisi suhu reaksi dan rasio konsentrasi pereaksi yang ditetapkan tidak memberikan pengaruh yang signifikan.

Derajat hidrogenasi tertinggi dihasilkan oleh karet hidrogenasi yang disintesis pada suhu $50{ }^{\circ} \mathrm{C}$ pada rasio konsentrasi hidrasina hidrat/hidrogen peroksida sebesar 42,5/30 phr. Pada suhu reaksi yang sama, konsentrasi hidrogen peroksida yang lebih besar cenderung memberikan derajat hidrogenasi yang lebih tinggi. Hidrogen peroksida merupakan oksidator kuat sehingga adanya hidrogen peroksida berlebih diperkirakan turut menyebabkan terjadinya reaksi samping pemutusan rantai panjang molekul karet alam menjadi rantai molekul yang lebih pendek. Namun terjadinya reaksi samping ini telah diminimalisasi karena sebagian besar sisa hidrogen peroksida yang tidak bereaksi dengan hidrasina hidrat telah dinetralkan oleh natrium tiosulfat. Penetralan tersebut dinilai cukup efektif yang juga terlihat dari fisik karet hidrogenasi yang kokoh dan tidak lengket. Jika reaksi samping pemutusan rantai molekul karet (depolimerisasi) menjadi dominan, maka akan diperoleh karet hidrogenasi yang memiliki tekstur lembek dan lengket. Dengan demikian dapat diketahui bahwa nilai derajat hidrogenasi tidak hanya menggambarkan pemutusan ikatan rangkap tetapi 
juga pemutusan rantai molekul karet alam.

Ketahanan oksidasi karet mentah karena pengaruh oksigen dan panas (thermal oxidative degradation) dievaluasi berdasarkan parameter plastisitas awal (Po) dan indeks ketahanan plastisitas (PRI). Nilai Po menggambarkan mikrostruktur karet alam yang mempengaruhi sifat mekaniknya sedangkan nilai PRI yang tinggi berkaitan dengan ketahanan karet mentah terhadap oksidasi panas yang baik (Bonfils et al., 2005). Hasil pengujian Po dan PRI karet terhidrogenasi dibandingkan dengan karet alam murni disajikan pada Gambar 4. Dari Gambar 4 dapat diketahui bahwa Nilai Po karet alam murni meningkat selama periode penyimpanan tertentu (Li et al., 1998). Nilai PRI karet alam murni yang sangat rendah dapat disebabkan karena terjadinya reaksi biokimia dalam lateks selama penyimpanan akibat adanya kontaminasi bakteri (Bonfils et al., 2005; Fri et al., 2007). Bakteri dapat menguraikan antioksidan alami yang terkandung dalam lateks sebagai bahan non karet (Baimark \& Niamsa, 2009). Selain itu akibat dari terdekomposisinya ikatan rangkap $\mathrm{C}=\mathrm{C}$ dalam rantai molekul karet alam murni pada suhu tinggi yang dipercepat dengan adanya oksigen saat pengujian PRI. Ikatan rangkap $\mathrm{C}=\mathrm{C}$ bersifat sangat reaktif terhadap oksigen dan radikal bebas hidroksil.

Sementara itu, nilai hasil pengujian PRI karet terhidrogenasi (Gambar 4) menunjukkan bahwa karet terhidrogenasi mentah memiliki sifat ketahanan oksidasi termal yang lebih baik daripada karet alam murni kecuali pada karet hidrogenasi mentah yang disintesis pada suhu $40{ }^{\circ} \mathrm{C}$ dengan rasio konsentrasi hidrasina hidrat/hidrogen peroksida sebesar 40/30 phr. Seluruh karet terhidrogenasi menghasilkan nilai PRI di atas nilai PRI karet alam mentah murni. Terputusnya ikatan rangkap $\mathrm{C}=\mathrm{C}$ ketika hidrogenasi meyebabkan berkurangnya ikatan $\mathrm{C}=\mathrm{C}$ tersebut dalam rantai molekul karet terhidrogenasi, sehingga bersifat tidak terlalu reaktif terhadap oksigen dan panas. Terbentuknya radikal hidroksil akibat terdekomposisinya hidrogen peroksida karena pengaruh panas juga dapat diminimalisasi karena sisa hidrogen peroksida yang tidak bereaksi telah dinetralkan oleh natrium tiosulfat di akhir reaksi hidrogenasi. Nilai PRI tertinggi diperoleh pada karet hidrogenasi yang disintesis pada suhu $50{ }^{\circ} \mathrm{C}$ dengan rasio konsentrasi hidrasina hidrat/hidrogen peroksida sebesar 42,5/35 phr. Pada kondisi tersebut diperkirakan bahwa konversi ikatan rangkap $\mathrm{C}=\mathrm{C}$ menjadi ikat- an tunggal C-C berlangsung optimal. Seiring dengan bertambahnya suhu dan konsentrasi pereaksi diikuti peningkatan konversi reaksi.

Secara alamiah rantai molekul poliisoprena penyusun karet alam mengandung fraksi sol dan fraksi gel (Nimpaiboon et al., 2013). Terbentuknya fraksi gel disebabkan oleh adanya interaksi antara senyawa non karet yaitu protein dan fosfolipid yang berada di ujung-ujung setiap rantai molekul karet melalui pembentukan ikatan silang selama masa simpan yang lama (Nawamawat et al., 2010; Nimpaiboon et al., 2014). Hasil perhitungan kadar gel karet terhidrogenasi ditampilkan pada Gambar 5. Dari Gambar 5 tampak bahwa pada suhu reaksi yang sama seiring dengan peningkatan rasio konsentrasi pereaksi terjadi penurunan kadar gel. Demikian pula dengan peningkatan suhu reaksi pada rasio konsentrasi pereaksi yang sama juga diikuti dengan penurunan kadar gel. Kondisi ini disebabkan karena terdekomposisinya ikatan silang antara protein dengan fosfolipid sepanjang reaksi hidro-

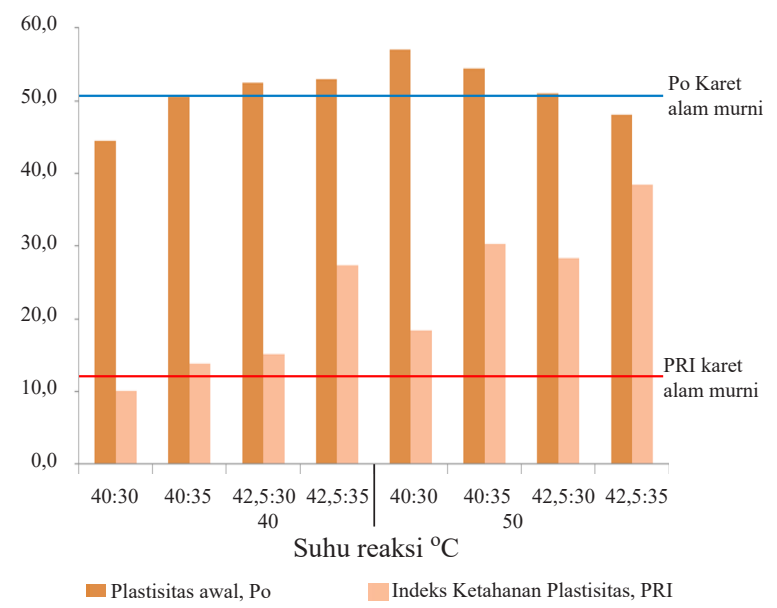

Gambar 4. Indeks Ketahanan Plastisitas (PRI) karet terhidrogenasi.

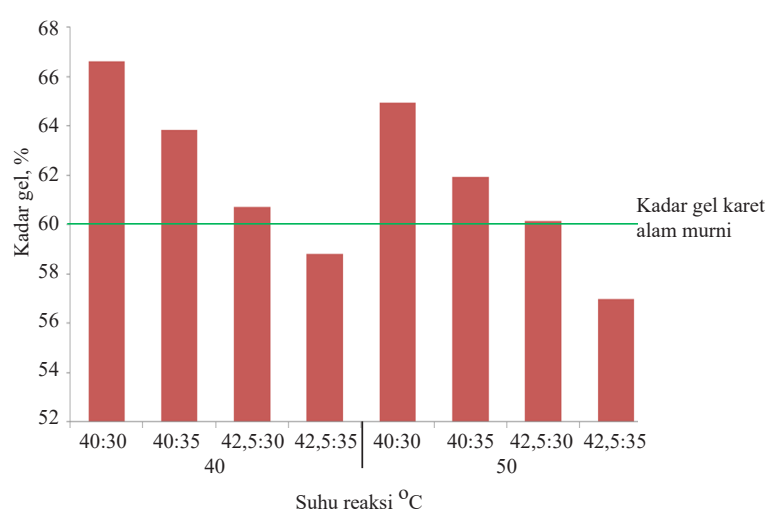

Gambar 5. Kadar gel karet terhidrogenasi. 
genasi berlangsung. Blackley (1997) memaparkan bahwa adanya senyawa polar dalam sistem koloid lateks karet alam menyebabkan penurunan kadar gel secara signifikan. Pada reaksi hidrogenasi, seluruh pereaksi yang terlibat bersifat polar sehingga akan menguraikan fraksi gel pada rantai molekul karet terhidrogenasi. Dengan kadar gel yang rendah maka risiko terjadinya pengerasan selama penyimpangan (storage hardening) pada karet terhidrogenasi dapat ditekan serendah mungkin. Secara alamiah, storage hardening pada molekul karet terjadi karena terbentuknya ikatan silang antar fraksi gel dalam rantai molekul karet. Hal ini menjadi keunggulan karet hidrogenasi selain ketahanan terhadap oksidasi termal. Storage hardening akan menyulitkan saat proses compounding.

\section{KESIMPULAN}

Kesimpulan yang dapat ditarik dari hasil kegiatan riset adalah bahwa kondisi optimal reaksi hidrogenasi lateks karet alam menggunakan senyawa diimida pada skala semi pilot berkapasitas $2,5 \mathrm{~kg}$ lateks pekat $/$ batch berkatalis asam borat tercapai pada suhu reaksi $50^{\circ} \mathrm{C}$ dengan dengan rasio konsentrasi hidrasina hidrat/hidrogen peroksida sebesar 42,5/35 phr. Pada kondisi reaksi tersebut, karet terhidrogenasi memiliki sifat ketahanan terhadap oksidasi termal yang lebih baik dibandingkan karet alam murni yang ditunjukkan dengan nilai indeks ketahanan plastisitas tertinggi sebesar 38,5 dan derajat hidrogenasi sebesar $60,48 \%$ serta kadar gel yang rendah sebesar $56,98 \%$. Penetralan sisa hidrogen peroksida yang tidak bereaksi oleh natrium tiosulfat dinilai efektif karena dapat meminimalisasi terbentuknya reaksi samping pemutusan rantai molekul karet (depolimerisasi) yang diindikasikan dengan visualisasi fisik karet terhidrogenasi yang kokoh, keras, dan tidak lengket.

\section{UCAPAN TERIMA KASIH}

Penulis memberikan perhargaan tinggi dan mengucapkan terima kasih kepada Kementerian Riset, Teknologi, dan Pendidikan Tinggi atas pendanaan kegiatan riset melalui program Insentif Sistem Inovasi Nasional (Insinas) Gelombang 2 Tahun Anggaran 2017 berdasarkan Surat Perjanjian Kerjasama (SPK) Nomor 10/ INS-2/PPK/E/E4/2017. Penulis turut berterima kasih kepada Sdr. Bimo Ekoyono, Mahasiswa Departemen Kimia, Institut Pertanian Bogor atas bantuan dalam menyelesaikan karakterisasi dan pengujian dalam riset ini.

\section{DAFTAR PUSTAKA}

Arayapranee, W., \& Rempel, G. L. (2009). Synthesis and mechanical properties of diimide hydrogenated natural rubber vulcanizates. Journal of Applied Polymer Science, 114, 4066 - 4075. https://doi.org/10.1002/app.31132

Arayapranee, W., \& Rempel, G. L. (2013). Effects of polarity on the filler-rubber interaction and properties of silica filled grafted natural rubber composite. Journal of Polymers, 2013, 1-9. https://doi.org/10.1155/2013/279529

Baimark, Y., \& Niamsa, N. (2009). Study on wood vinegars for use as coagulating and antifungal agents on the production of natural rubber sheets. Biomass and Bioenergy, 33, 994-998. https://doi.org/10.1016/j.biombioe.2009.04.001

Blackley, D. C. (1997). Polymer latices: Science and technology $\mathrm{Vol}$ 3. Application of latices. Netherlands: Springer.

Bonfils, F., Doumbia, A., Char, C., \& Sainte Beuve, J. (2005). Evolution in the natural rubber native structure and plasticity retention index from the first tapping of clonal trees. Journal of Applied Polymer Science, 97, 903-909.

https://doi.org/10.1002/app.21845

Cifriadi, A., Chalid, M., \& Puspitasari, S. (2017a). Characterization of hydrogenated natural rubber synthesize by diimide transfer hydrogenation. International Journal of Technology, 8(3), 448457.

https://doi.org/10.14716/ijtech.v8i3.1991

Cifriadi, A., Chalid, M., \& Puspitasari, S. (2017b). Effect of urea deproteinization on catalytic hydrogenation of natural rubber latex. IOP Conference Series: Materials Science and Engineering 223. https://doi.org/10.1088/1757-899X/223/1/012010

Fri, P. S., Nkeng, G. E., \& Ehabe, E. E. (2007). Effect of natural coagulation maturation on the processability, cure, and mechanical properties of unfilled vulcanizates of Hevea natural rubber. Journal of Applied Polymer Science, 103, 23592363. https://doi.org/10.1002/app.25175

Ibrahim, S., Daik, R., \& Abdullah, I. (2014). Functionalization of liquid natural rubber via oxidative degradation of natural rubber. Polymers, 6, 2928-2941.

https://doi.org/10.3390/polym6122928

Inoue, S., \& Nishio, T. (2007). Synthesis and properties of hydrogenated natural rubber. Journal of Applied Polymer Science, 103, 3957-3963. https://doi.org/10.1002/app.25158

Kongparakul, S., Ng, F. T. T., \& Rempel, G. L. (2011). Metathesis hydrogenation of natural rubber latex. Applied Catalysis A: General, 405, 129-136. https://doi.org/10.1016/j.apcata.2011.07.039

Li, S. D., Yu, H. P., Peng, Z., \& Li, P. S. (1998). Study 
on variation of structure and properties of natural rubber during accelerated storage. Journal of Applied Polymer Science, 70, 1779-1783.

Lin, X., Pan, Q., \& Rempel, G. L. (2004). Hydrogenation of nitrile butadiene rubber latex with diimide. Applied Catalysis A: General, 276, 123-128. https://doi.org/10.1016/j.apcata.2004.07.049

Mahittikul, A., Prasassarakich, P., \& Rempel, G. L. (2006). Hydrogenation of natural rubber latex in the presence of $\mathrm{OsHCl}(\mathrm{CO})\left(\mathrm{O}_{2}\right)\left(\mathrm{PCy}_{3}\right)_{2}$. Journal of Applied Polymer Science, 100, 640-655. https://doi.org/10.1002/app.23390

Mahittikul, A., Prasassarakich, P., \& Rempel, G. L. (2007). Diimide hydrogenation of natural rubber. Journal of Applied Polymer Science, 105, 11881199. https://doi.org/10.1002/app.25944

Mahittikul, A., Prasassarakich, P., \& Rempel, G. L. (2009). Hydrogenation of natural rubber latex in the presence of $\left[\operatorname{Ir}(\operatorname{cod})\left(\mathrm{PCy}_{3}\right)(\mathrm{py})\right] \mathrm{PF}_{6}$. Journal of Molecular Catalysis A: Chemical, 297, 135-141. https://doi.org/10.1016/j.molcata.2008.09.006

Nawamawat, K., Sakdapipanich, J.T., \& Ho, C.C. (2010). Effect of deproteinized methods on the properties of natural rubber latex during storage. Macromolecular Symposia, 288, 95-103. https://doi.org/10.1002/masy.201050212

Nimpaiboon, A., Amnuaypornsri, S., \& Sakdapipanich, J. (2013). Influence of gel content on the physical properties of unfilled and carbon black filled natural rubber vulcanizates. Polymer Testing, 32(6), 1135-1144. https://doi.org/10.1016/j.polymertesting.2013.07.003
Nimpaiboon, A., Amnuaypornsri, S., \& Sakdapipanich, J. (2014). Role of gel content on the structural changes of masticated natural rubber. Advanced Material Research, 844, 101-104.

Piya-areetham, P., Prasassarakich, P., \& Rempel, G. L. (2013a). Organic solvent-free hydrogenation of natural rubber latex and synthetic polyisoprene emulsion catalyzed by water-soluble rhodium complexes. Journal of Molecular Catalysis A: Chemical, 372, 151-159. https://doi.org/10.1016/j.molcata.2013.02.025

Piya-areetham, P., Prasassarakich, P. \& Rempel, G. L. (2013b). Aqueous-phase hydrogenation of nanosized polyisoprene emulsion using rhodium catalysts. European Polymer Journal, 49, 25842595.

https://doi.org/10.1016/j.eurpolymj.2013.05.025

Puviarasan, N., Arjunan, V., \& Mohan, S. (2004). FTIR and FT-Raman spectral investigations on 4-aminoquinaldine and 5-aminoquinoline. Turkish Journal of Chemistry, 28, 53-65.

Veni, B.N.K. \& Ma'zam, M.S. (2010). Hydrogenated natural rubber from different types of preserved latex. Journal of Rubber Research, 13(2), 103109.

Wang, D., \& Astruc, D. (2015). The golden age of transfer hydrogenation. Chemical Reviews, $115(13), 6621-6686$. 